\title{
TEACHING FACTORY SEBAGAI UPAYA PENINGKATAN MUTU LULUSAN DI SMK
}

\section{TEACHING FACTORY AS AN EFFORT TO IMPROVE THE QUALITY OF GRADUATES IN VOCATIONAL SCHOOL}

\author{
Sudiyono, S.Pd., M.Pd. \\ Pusat Penelitian Kebijakan Pendidikan dan Kebudayaan, \\ Kementerian Pendidikan dan Kebudayaan \\ sudiyono_d@ymail.com \\ Naskah diterima: 13 Agustus 2019; direvisi akhir: 21 Desember 2019; disetujui: 17 Januari 2020
}

\begin{abstract}
ABSTRAK
Penelitian ini bertujuan untuk mendapatkan rekomendasi kebijakan tentang pelaksanaan teaching factory sebagai upaya Peningkatan Mutu Lulusan di SMK. Penelitian merupakan studi lapangan bersifat deskriptif analisis. Pengumpulan data dilakukan dengan teknik studi dokumentasi, penyebaran kuesioner, dan Diskusi Kelompok Terpumpun (DKT). Lokasi penelitian di 5 wilayah, yaitu; Kota Padang, Kota Malang, Kota Surakarta, Kota Denpasar, dan Kota Bandung dengan jumlah sampel sebanyak 15 SMK yang telah melaksanakan program teaching factory. Sampel studi adalah kepala sekolah, guru produktif, dan pengelola teaching factory berjumlah 45 orang. Hasil penelitian menunjukkan bahwa SMK belum memahami fungsi teaching factory, tampak dari lemahnya perencanaan, pelaksanaan pembelajaran, kegiatan produksi, dan kerjasama industry. Tegasnya teaching factory masih kurang berdampak terhadap peningkatan mutu lulusan di SMK, serta memerlukan upaya pendampingan, terutama pelibatan DUDI yang lebih optimal.
\end{abstract}

Kata kunci: teaching factory; Pendidikan vokasi, SMK, mutu lulusan, efektivitas

\section{ABSTRACT}

This study aims to formulate policy recommendations regarding the implementation of teaching factory as an effort to improve the quality of graduates in vocational high schools. Method of study is a descriptive analytical field study. Data collection was carried out by means of documentation study techniques, questionnaires and Focus Group Discussion (FGD). Research was carried out in 5 regions; The city of Padang, the city of Malang, the city of Surakarta, the city of Denpasar, and the city of Bandung with a total sample of 15 vocational schools that have implemented a teaching factory program. The study's sample was 45 principals, technical teachers, and teaching factory managers. The results showed that vocational high schools had not understand the function of teaching factory, it was seen from the lack of detailed planning, implementation of learning, production activities, and industrial cooperation. Strictly speaking, teaching factories still have less impact on improving the quality of graduates in vocational high schools, and require mentoring efforts, especially a more optimal involvement of the industries.

Keywords: teaching factory; Vocational education, SMK, graduate quality, effectiveness 


\section{PENDAHULUAN}

Peraturan Pemerintah (PP) No. 66 Tahun 2010 menyebutkan bahwa Sekolah Menengah Kejuruan (SMK) merupakan salah satu jenjang pendidikan menengah dengan kekhususan mempersiapkan lulusannya untuk siap bekerja. Agar lulusan SMK siap bekerja di dunia kerja atau industri pemerintah berupaya (a) memperkuat kemampuan adaptif yang meliputi kemampuan matematika terapan dan sains terapan, (b) memperkuat kemampuan berwirausaha, (c) memperkuat kemampuan berbahasa nasional dan internasional, (d) memperkuat kemampuan dasar TIK, (e) dan melaksanakan teaching factory (Direktorat PSMK, 2010).

Keberadaan SMK diharapkan dapat mendukung pertumbuhan ekonomi melalui kegiatan kewirausahaan atau bekerja di dunia usaha dan dunia industri. Data BPS tahun 2017 menunjukkan bahwa keberadaan jumlah SMK yang semakin banyak berbanding lurus dengan Peningkatan Pendapatan Domestik Regional Bruto (PDRB). Hal ini mengindikasikan bahwa keberadaan SMK turut berkontribusi terhadap peningkatan PDRB. Walaupun peningkatan PDRB juga dipengaruhi oleh faktor lain, setidaknya terdapat indikasi bahwa lulusan SMK berkontribusi terhadap pembangunan ekonomi.

Dukungan terhadap pertumbuhan ekonomi dan peningkatan sumber daya manusia, menjadi alasan pemerintah terus menambah jumlah SMK secara bertahap dari tahun ke tahun di seluruh Indonesia. Data Badan Pusat Statistik (BPS) tahun 2013/2014 mencatat jumlah SMK aktif sebanyak 11.738 sekolah yang terdiri dari 3.037 SMK negeri dan 8.701 SMK swasta yang tersebar di tiga puluh empat provinsi di Indonesia, dengan jumlah siswa sebanyak 4.199.657 orang dan jumlah guru 186.401 orang. Selanjutnya data PDSP tahun 2015/2016 mencatat jumlah SMK di seluruh Indonesia sebanyak 12.659 sekolah, terdiri dari $3.320(26,23 \%)$ SMK negeri dan 9.339 (73,77\%) SMK swasta dengan jumlah siswa sebanyak 4.334.987 orang. Dari data dapodik tahun 2017, jumlah kompetensi keahlian terbanyak adalah Teknik Komputer dan Jaringan (TKJ).

Namun, banyaknya jumlah SMK ternyata juga ikut menyumbang angka pengangguran. Berdasarkan data BPS bulan Agustus 2014, tingkat pengangguran terbuka lulusan SMK sebesar 11,24\% dan meningkat menjadi $12,65 \%$ pada periode bulan Agustus 2015. Selanjutnya untuk bulan Februari 2016 terjadi penurunan menjadi 9,84\% jika dibandingkan dengan bulan Agustus 2015. Pada bulan Agustus 2017 terjadi peningkatan pengangguran terbuka menjadi $11,41 \%$ sedangkan untuk perionde bulan Februari 2018 terjadi penurunan tingkat pengangguran terbuka SMK menjadi 8,92\%. Tingkat pengangguran terbuka lulusan SMK dipengaruhi oleh banyak faktor, di antaranya terkait dengan ketersediaan jumlah lowongan kerja yang tidak sesuai dengan kompetensi yang dimiliki siswa.

Keterserapan lulusan SMK pada tahun 2017 cenderung meningkat, sementara tingkat pengangguran terbuka tahun 2018 menurun. Hal ini menunjukkan bahwa lulusan SMK semakin banyak diminati dan mendapatkan pekerjaan pada tahun 2018. Namun dari data BPS tahun 2018 tingkat pengangguran terbuka SMK sebesar 8,92\% masih merupakan angka tertinggi jika dibandingkan dengan tingkat pendidikan lainnya. Diduga, tingginya 
tingkat pengangguran SMK disebabkan oleh empat hal: terjadi oversupply, yakni lulusan SMK jurusan tertentu jumlahnya berlebih ketimbang yang lain; tidak sesuainya jurusan SMK tertentu dengan industri yang membutuhkan di wilayahnya; kualitas lulusan yang tidak sesuai standar industri,; dan usia lulusan yang rata-rata baru 17 tahun, sehingga harus menunggu 1 tahun lagi untuk bekerja. (Media Indonesia 11/5/18).

Untuk menyiapkan lulusan SMK yang bermutu, sejak tahun 1990 pemerintah telah membentuk unit usaha sebagai kegiatan praktik. Peraturan Pemerintah No. 29 Tahun 1990 pasal 29 ayat (2) menyebutkan bahwa untuk mempersiapkan siswa menjadi tenaga kerja, sekolah menengah kejuruan dapat mendirikan unit produksi yang beroperasi secara profesional. Unit produksi adalah aktivitas usaha sekolah terhadap program pendidikan dan latihan (diklat), dalam upaya mengoptimalkan sumber daya yang dimiliki agar memberikan nilai tambah yang lebih besar untuk mendukung pelaksanaan program sekolah.

Upaya peningkatan mutu SMK terus dilakukan, tahun 2005 pemerintah melalaui direktorat pembinaan SMK telah memberikan bantuan sarana pembangunan 50 Edotel (education hotel) sebagai tempat kegiatan pembelajaran dan sarana praktik perhotelan dengan menghadirkan industri di sekolah, sehingga siswa dapat melakukan kegiatan peraktik senyatanya. Selain digunakan sebagai tempat kegatan, Edotel juga menjadi unit produksi yang dapat dikembangkan sekolah untuk menunjang biaya operasional. Selanjutnya unit produksi menjadi model pembelajaran dengan menerapkan sistem industri mitra di unit yang ada di SMK yang dikenal dengan model pembelajaran teaching factory (Tefa). Secara konseptual, pembelajaran teaching factory adalah model pembelajaran di SMK berbasis produksi/jasa yang mengacu pada standar dan prosedur yang berlaku di industri dan dilaksanakan dalam suasana seperti di industri. Pelaksanaan teaching factory menuntut keterlibatan mutlak pihak industri sebagai pihak yang relevan menilai kualitas hasil pendidikan di SMK. Konsepsi dasar teaching factory bertujuan untuk melakukan transfer lingkungan produksi di industri ke dalam ruang praktik di kelas. Kehidupan produksi yang sesungguhnya sangat dibutuhkan untuk meningkatkan kompetensi pembelajaran berbasis aktivitas nyata dari praktik industri setiap harinya.

Penerapan konsep teaching factory di SMK sejak tahun 2005 berkembang menjadi sebuah model pengembangan SMK berbasis industri. Tahun 2011 SMK berbasis industri berkembang dalam bentuk factory sebagai tempat belajar, selanjutnya dikenal dengan teaching factory. Penyelenggaraan model ini memadukan sepenuhnya antara belajar dan bekerja, tidak lagi memisahkan antara tempat penyampaian teori dan praktik.

Pemerintah terus menambah jumlah SMK rujukan untuk menjadi model teaching factory. Jumlah SMK rujukan yang telah memiliki teaching factory tahun 2015 sebanyak 160 SMK, tahun 2018 menjadi sebanyak 425 SMK, dan ditargetkan tahun 2019 mencapai 500 SMK (Direktorat Pembinaan SMK, 2015).

Terkait dengan hal tersebut kiranya perlu dikaji bagaimana efektivitas pelaksanaan model teaching factory di SMK sebagai upaya meningkatkan mutu lulusan. Tulisan 
ini merupakan bagian dari penelitian mengenai topik tersebut untuk mendapatkan bahan rumusan kebijakan model teaching factory di SMK sebagai upaya meningkatkan mutu lulusan di SMK, dengan fokus kajian terhadap bidang pariwisata. Bahasan mencakup penyelenggaraan teaching factory, dampak, dan kendala yang dihadapi, kemudian menarik kesimpulan sebagai bahan rekomendasi untuk pengambilan kebijakan.

\section{KAJIAN PUSTAKA}

\section{Sekolah Menengah Kejuruan}

Pendidikan kejuruan pada hakikatnya merupakan subsistem dari sistem pendidikan. Undang-Undang Negara Republik Indonesia Nomor 20 Tahun 2003 tentang Sistem Pendidikan Nasional Pasal 18 menjelaskan bahwa pendidikan kejuruan merupakan pendidikan menengah yang mempersiapkan peserta didik untuk bekerja pada bidang tertentu. Oleh karena itu, tujuan penyelenggaraan sekolah menengah kejuruan (SMK)dimaksudkanuntukmenyiapkansiswa: 1) memasuki lapangan pekerjaan tertentu serta mengembangkan sikap profesional; 2) memiliki bekal dan kemampuan memilih karir, mampu berkompetisi, dan mampu mengembangkan diri; 3) menjadi tenaga kerja tingkat menengah yang mandiri dan/atau mengisi kebutuhan dunia usaha dan industri pada saat ini maupun masa yang akan datang.

Dengan demikian, keberadaan SMK dimaksudkan untuk menciptakan tenaga kerja yang memiliki kompetensi sesuai program keahlian masing-masing. SMK dikatakan berhasil manakala para lulusan sekolah tersebut dapat diserap oleh dunia usaha dan dunia industri (DU/DI) sesuai program keahliannya dan kompetensi keahlian masing-masing. Kompetensi lulusan SMK dituntut untuk menyelaraskan pada kebutuhan DU/DI sebagai penyedia lapangan kerja dengan memformulasikan silabus atau kurikulum yang berorientasi pada kompetensi dan tuntutan dunia kerja sesuai kebutuhan di daerah masing-masing pada masa sekarang dan masa yang akan datang. Oleh karena itu, setiap SMK harus berupaya menyesesuaikan kurikulum sesuai dengan perkembangan iptek dan kebutuhan DU/DI. Namun demikian, tidak berarti bahwa SMK hanya sekadar untuk mempersiapkan tenaga kerja yang siap pakai, tetapi SMK juga berperan sebagai lembaga pendidikan formal yang bertugas mempersiapkan sumber daya manusia (SDM) Indonesia yang berkarakter, mampu mengikuti perkembangan pengetahuan dan teknologi serta menjadi manusia yang produktif.

Penyelenggaraan SMK setidaknya memiliki 9 (sembilan) karakteristik, (Wardiman dalam Sudira, 2006) yaitu:

- Mempersiapkan peserta didik memasuki lapangan kerja;

- Berorientasi pada kebutuhan lapangan kerja (demand driven);

- Penguasaan kompetensi yang dibutuhkan oleh dunia kerja;

- Kesuksesan peserta didik pada "handson" atau performa dunia kerja;

- Memiliki hubungan erat dengan dunia kerja sebagai kunci sukses pendidikan kejuruan;

- Responsif dan antisipatif terhadap kemajuan teknologi;

- Learning by doing dan hands on experience;

- Membutuhkan fasilitas mutakhir untuk praktik; dan 
- Memerlukan biaya investasi dan operasional yang lebih besar.

Berdasarkan karakteristik tersebut, diharapkan para lulusan SMK berkarakter sebagai calon tenaga kerja tingkat menengah yang berkepribadian secara utuh sebagai warga negara dan sebagai warga pekerja yang berbekal keterampilan/kompetensi untuk bekerja di bidang tertentu sesuai dengan tuntutan DU/DI. Oleh karena itu, agar para lulusan SMK memiliki wawasan kerja secara nyata, penyelenggaraan pendidikan di SMK dilaksanakan dengan sistem ganda (dual system) melalui praktik kerja (prakerin) sebagai realisasi program pendidikan sistem ganda di sekolah dan di DU/DI.

Pelaksanaan pendidikan SMK akan mencapai sasaran manakala dapat menerapkan prinsip-prinsip bahwa pendidikan kejuruan efisien jika ditunjang lingkungan yang kondusif, di mana peserta didik dilatih/ dipersiapkan dan dikenalkan sebagaimana suasana bekerja di DU/DI. Pendidikan SMK akan efektif jika tugas-tugas pendidikan (di sekolah) dan tugas latihan kerja (di DU/DI) dapat dilaksanakan secara terpadu, terkait dan sepadan serta ditunjang oleh fasilitas peralatan yang kurang lebih sama (media simulasi) seperti yang digunakan di DU/DI.

Pendidikan SMK akan efektif jika melatih kebiasaan peserta didik berpikir dan bekerja seperti di DU/DI, setiap individu mengembangkan minat, meningkatkan pengetahuan, dan kompetensinya secara optimal untuk bekal kerja. Pendidikan SMK juga akan efektif jika pendidikan dan pelatihan mampu membentuk kebiasaan bekerja dengan tekun, teliti, cermat, cerdas dan smart serta tangggungjawab melalui pembiasaan berpikir sistemik.
Di samping itu, SMK juga berfungsi: 1) sebagai training center/BLK daerah; 2) sebagai testing center; 3) sebagai teaching factory; 4) sebagai outlet layanan penempatan lulusan dan tenaga kerja; dan 5) sebagai pusat bisnis dan pengembangan waralaba bagi masyarakat (Dikdasmen, 2005). Salah satu usaha untuk mencapai multi fungsi SMK tersebut adalah mendirikan unit produksi yang berfungsi 1) menjadi pusat pelatihan, karena di dalamnya ada kegiatan untuk memperdalam kemampuan keterampilan, 2) sebagai industri, karena akan menghasilkan produk atau jasa yang dibutuhkan konsumen, 3) penyedia tenaga kerja terampil, karena menghasilkan tamatan yang memiliki ilmu pengetahuan, keterampilan dan sikap kerja yang dibutuhkan industri, 4) tempat seleksi tenaga kerja secara rutin setiap tahun sehingga memudahkan industri dalam memilih tenaga kerja sesuai spesifikasi dan kebutuhan industri tanpa harus mengeluarkan biaya promosi lowongan tenaga kerja, 5) menjadi pusat informasi tenaga kerja bagi masyarakat luas khususnya alumni dan SMK lainnya di wilayah terdekat.

Pendidikan kejuruan akan efektif(Prosser, 1949) jika terdapat hal-hal antara lain: 1) disediakan lingkungan yang sesuai dengan kondisi nyata tempat lulusan akan bekerja; 2) latihan kejuruan diberikan tugas atau program sesuai dengan apa yang dikerjakan di industri; 3) kegiatan praktek dan tugas diberikan dengan mengerjakan produk yang sesungguhnya, bukan sekedar tiruan. 4) dalam latihan kerja atau dalam pengerjaan tugas sudah dibiasakan pada kondisi sennyatanya; 5) program-progam yang disediakan bervariasi meliputi semua profesi serta mampu dimanfaatkan atau ditempuh 
oleh peserta didik; 6) diberikan secara berulang kali hingga diperoleh penguasaan yang memadai kepada peserta didik; 7) para guru dan instrukturnya berpengalaman dan mampu mentransfer ilmu kepada peserta didik; 8) mampu memberikan bekal kemampuan minimal yang dibutuhkan dunia kerja sehingga mudah pengembangannya; 9) memperhatikan kondisi pasar; 10) proses pemantapan belajar dan latihan peserta didik dalam pendidikan kejuruan akan diberikan secara proporsional.

\section{Model teaching factory}

teaching factory merupakan konsep pembelajaran dalam keadaan yang sesungguhnya untuk menjembatani kesenjangan kompetensi antara pengetahuan yang diberikan sekolah dan kebutuhan industri (Kuswantoro (2014). Penerapan model pembelajaran teaching factory dapat menjadi salah satu inovasi pembelajaran di sekolah untuk pengembangan kompetensi guru dan peserta didik. Pelaksanaan pembelajaran model teaching factory melibatkan industri mitra dengan memanfaatkan unit produksi sebagai salah satu bentuk pengembangan usaha di sekolah. Penerapan teaching factory secara optimal di SMK diharapkan mampu mengembangkan kompetensi peserta didik sesuai dengan karakteristik kebutuhan dunia industri, karena melalui model teaching factory siswa tidak hanya sekedar belajar bagaimana menguasai sebuah kompetensi, tetapi juga dapat menghasilkan keuntungan dari penjualan produk/jasa dari kegiatan praktek pada unit produksi tertentu. Selain itu, pihak sekolah juga mendapatkan manfaat baik dari segi pengembangan kompetensi guru maupun penerapan sistem pengembangan usaha berbasis industri dengan memperoleh keuntungan.

Pembelajaran teaching factory adalah suatu konsep pembelajaran di SMK berbasis produksi/jasa yang mengacu kepada standar dan prosedur yang berlaku di industri, dan dilaksanakan dalam suasana seperti yang terjadi di industri. Hal ini sesuai karakteristik pendidikankejuruanyaitu:(1)mempersiapkan peserta didik memasuki lapangan kerja; (2) didasarkan kebutuhan dunia kerja "marketdriven demand"; (3) penguasaan kompetensi yang dibutuhkan dunia kerja; (4) kesuksesan siswa pada "hands on" atau performa dunia kerja; (5) hubungan erat dengan dunia kerja; (6) responsif dan antisipatif terhadap kemajuan teknologi; (7) learning by doing dan hands on experience; (8) memerlukan biaya investasi dan operasional yang lebih besar dari pendidikan umum (Herminarto Sofyan, dkk).

Terdapat tiga hal mendasar dari konsep teaching factory, yaitu: (1) pembelajaran yang biasa saja tidak cukup, (2) keuntungan peserta didik diperoleh dari pengalaman praktik secara langsung, dan (3) pengalaman pembelajaran berbasis team yang melibatkan siswa, staf pengajar dan partisipasi industri memperkaya proses pendidikan dan memberikan manfaat yang nyata bagi semua pihak (Lamancusa, 2008).

Konsep teaching factory mengadaptasi dari metode pembelajaran Dual System yang telah lama diterapkan dalam pendidikan TVET di negara Jerman dan Swiss. Metode pembelajaran ini merupakan metode yang mengintegrasikan dua lingkungan utama dalam setiap kegiatan peserta didik, yakni lingkungan sekolah dan lingkungan perusahaan(industri). Pesertadidiktidakhanya 
melakukan kegiatan belajar di sekolah, tetapi juga melakukan praktik (kompetensi dasar) dan kerja (mengaplikasikan kompetensinya) di industri dalam jangka waktu yang relatif panjang. Secara fundamental, Dual System bertujuan untuk menempatkan peserta didik dalam situasi nyata di tempat kerja secara menyeluruh. Dengan praktik yang demikian, peserta didik tidak hanya memperoleh pengetahuan teoritis, tetapi juga mampu menerapkan praktik berbasis produksi sebagaimana yang selalu diterapkan dalam kegiatan industri. Hal ini membuat peserta didik mampu memperoleh keterampilan, proses dan sikap yang sesuai dengan standar industri sehingga hasil pendidikan sesuai dengan kebutuhan industri.

Kondisi ideal implementasi teaching factory di SMK (Direktorat Pembinaan SMK, 2017), meliputi aspek-aspek dan sub aspek sebagai berikut: 1) Aspek Pembelajaran, bahan ajar mempunyai tujuan untuk mencapai kompetensi tertentu dan merupakan sesuatu yang multiguna (marketable), khusus untuk program kompetensi yang tidak menghasilkan produk/jasa dapat diarahkan pada simulasi dari situasi kerja riil di lapangan, sistem penilaian yang digunakan sudah berbasis teaching factory dan sistem pembelajaran menggunakan jadwal blok dan kontinyu. 2) Sumber Daya Manusia, sumber daya manusia mempunyai kemampuan design engineering dan dapat menerapkan sense of quality, sense of efficiency dan sense of innovation. Untuk proses kegiatan belajar harus memperhatikan rasio jumlah guru dan jumlah peserta didik. 3) Fasilitas, fasilitas yang dimiliki sekolah harus memenuhi rasio 1: 1 antara peserta didik dan alat, penanganan perawatan sudah menerapkan MRC (Maintanance, Repair, and Calibration), untuk alat bantu proses sudah sesuai dan lengkap, seluruh peralatan di kembangkan terus menerus (penambahan dan penggantian alat). 4) Kegiatan Praktik, menerapkan budaya industri dengan adanya standar kualitas (quality control), target waktu, efisiensi proses produksi, rotasi kerja (shift), produk kerja yang jelas, hasil praktik dapat menjadi sumber pendapatan (generating income), fungsi dan tanggung jawab yang jelas untuk setiap penanggung jawab, lingkungan kerja dibuat dan dijaga sehingga jadi aman dan nyaman, kegiatan pembelajaran teratur dan lancar, kontrol dan pemantauan dilakukan secara terus menerus. 5) Jaringan Kerjasama (Network), sekolah mempunyai kerjasama dengan industri, baik untuk transfer teknologi maupun membangun budaya industri di sekolah. 6) Produk dan Jasa, produk dan jasa yang dihasilkan sudah sesuai dengan standar industri. 7) Transparansi, pencatatan transaksi keuangan sudah sesuai dengan standar prosedur akuntansi (tata kelola keuangan). 8) Aspek legal berupa peraturan harus tersedia untuk penyelenggaraan teaching factory.

Tujuan Penerapan teaching factory (Dit. Pembinaan SMK 2017) antara lain: 1) mempersiapkan lulusan SMK yang siap kerja; 2) membantu siswa memilih bidang kerja yang sesuai dengan kompetensinya; 3) memberi kesempatan kepada guru SMK untuk membangun jembatan instruksional antara kelas dan dunia kerja; 4) membuat pembelajaran lebih menarik dan memotivasi siswa belajar; 5) sarana pelatihan dan praktik berbasis produksi secara langsung bagi siswa SMK yang berorientasi pada pasar; 6) tercapainya tujuan SMK dalam upaya penciptaan atau pembentukan SDM 
yang memiliki kompetensi sesuai dengan kebutuhan DU/DI; 7) membantu pendanaan untuk pemeliharaan, penambahan fasilitas dan biaya-biaya operasional SMK dan peningkatan kesejahteraan; 8) ,enumbuhkan dan mengembangkan jiwa wirausaha guru dan siswa; 9) mengembangkan sikap mandiri dan percaya diri siswa SMK melalui kegiatan produksi.

Tujuan umum teaching factory adalah: 1) pengintegrasian pengalaman dunia kerja ke dalam kurikulum sekolah; 2) proses pembelajaran berbasis industri produk/ jasa melalui sekolah dengan industri yang berjalan secara sinergi; 3) pola kebiasaan pembelajaran yang terkesan "dunia sekolah" diubah menjadi "dunia industri" dalam bentuk learning by doing dan hands on experience; 4) untuk menyelenggarakan teaching factory, sekolah diharuskan memiliki pabrik sekolah/ workshop/unit usaha lain; dan 5) keberhasilan pelaksanaan pembelajaran tidak hanya terletak pada kegunaan dan kualitas produk, tetapi juga terletak pada kualitas SDM (guru dan peserta didik), lingkup hubungan kerja sama dengan industri, dan pembekalan pengetahuan kewirausahaan.

\section{Efektifitas teaching factory}

Efektifitas dalam suatu program selalu terkait hubungan antara hasil yang diharapkan dengan hasil yang telah dicapai. Efektifitas dapat dilihat dari berbagai sudut pandang, dinilai dengan berbagai cara, dan mempunyai kaitan yang erat dengan efisiensi. Efektifitas dimaknai sebagai tingkat keberhasilan organisasi dalam usaha untuk mencapai tujuan dan sasaran (Etzioni, dkk dalam Hamzah, 2013). Efektifitas juga didefinisikan sebagai suatu keadaan yang menunjukkan tingkatan keberhasilan manajemen dalam mencapai tujuan yang telah ditetapkan terlebih dahulu (Komaruddin (1994). Pada dasarnya, dalam memaknai efektifitas setiap orang dapat memberi arti yang berbeda sesuai sudut pandang dan kepentingan masing-masing.

Efektivitas merupakan unsur pokok untuk mencapai tujuan yang telah ditentukan di dalam suatu program kegiatan. Suatu program dikatakan efektif apabila tujuan tercapai sesuai dengan rencana yang telah ditentukan (Emerson).

Efektivitas ditinjau dari sudut pencapaian tujuan, bahwa untuk mencapai keberhasilan suatu organisasi perlu mempertimbangkan sasaran dan mempertahankan diri dalam mengejar sasaran. Dapat dikatakan, penilaian efektivitas harus berkaitan dengan sasaran maupun tujuan.

Dari beberapa pengertian tentang efektivitas sebagaimana disebutkan di atas dapat disimpulkan bahwa efektivitas adalah suatu ukuran yang menyatakan seberapa jauh target (kuantitas, kualitas, dan waktu) yang telah dicapai oleh manajemen, yang mana target tersebut sudah ditentukan terlebih dahulu. Hal ini sesuai dengan pendapat yang dikemukakan oleh Hidayat (1986) yang menjelaskan bahwa efektivitas adalah suatu ukuran yang menyatakan seberapa jauh target (kuantitas, kualitas dan waktu) telah tercapai. Dimana makin besar persentase target yang dicapai, makin tinggi efektivitasnya.

Kegiatan mengevaluasi jalannya suatu organisasi, dapat dilakukan melalui konsep efektivitas. Konsep ini adalah salah satu faktor untuk menentukan apakah perlu dilakukan perubahan secara signifikan terhadap bentuk dan manajemen organisasi atau tidak. Dalam hal ini efektivitas merupakan pencapaian 
tujuan organisasi melalui pemanfaatan sumber daya yang dimiliki secara efisien, ditinjau dari sisi masukan (input), proses, maupun keluaran (output). Sumber daya yang dimaksudkan disini meliputi ketersediaan personil, sarana dan prasarana serta metode dan model yang digunakan. Suatu kegiatan dikatakan efisien apabila dikerjakan dengan benar dan sesuai dengan prosedur sedangkan dikatakan efektif bila kegiatan tersebut dilaksanakan dengan benar dan memberikan hasil yang bermanfaat.

Mengukur efektivitas suatu program dapat dilihat dari berbagai dimensi tergantung siapa yang menilai serta menginterpretasikannya. Tingkat efektivitas juga dapat diukur dengan membandingkan antara rencana yang telah ditentukan dengan hasil nyata yang telah diwujudkan. Namun, jika usaha atau hasil pekerjaan dan tindakan yang dilakukan tidak tepat sehingga menyebabkan tujuan tidak tercapai atau sasaran yang diharapkan, maka hal itu dikatakan tidak efektif. Kriteria atau ukuran tingkat efektifitas dalam mencapai tujuan adalah sebagai berikut (S.P. Siagian).

a) Kejelasan tujuan yang hendak dicapai, hal ini dimaksudkan supaya karyawan dalam pelaksanaan tugas mencapai sasaran yang terarah dan tujuan organisasi dapat tercapai.

b) Kejelasan strategi pencapaian tujuan, telah diketahui bahwa strategi adalah "pada jalan" yang diikuti dalam melakukan berbagai upaya dalam mencapai sasaran-sasaran yang ditentukan agar para implementer tidak tersesat dalam pencapaian tujuan organisasi.

c) Proses analisis dan perumusan kebijakan yang mantap, berkaitan dengan tujuan yang hendak dicapai dan strategi yang telah ditetapkan artinya kebijakan harus mampu menjembatani tujuan-tujuan dengan usaha-usaha pelaksanaan kegiatan operasional.

d) Perencanaan yang matang, pada hakekatnya berarti memutuskan sekarang apa yang dikerjakan oleh organisasi di masa depan.

e) Penyusunan program yang tepat suatu rencana yang baik masih perlu dijabarkan dalam program-program pelaksanaan yang tepat sebab apabila tidak, para pelaksana akan kurang memiliki pedoman bertindak dan bekerja.

f) Tersedianya sarana dan prasarana kerja, salah satu indikator efektivitas organisasi adalah kemampuan bekerja secara produktif dengan sarana dan prasarana yang tersedia dan mungkin disediakan oleh organisasi.

g) Pelaksanaan yang efektif dan efisien, bagaimanapun baiknya suatu program apabila tidak dilaksanakan secara efektif dan efisien maka organisasi tersebut tidak akan mencapai sasarannya, karena dengan pelaksanaan organisasi semakin didekatkan pada tujuannya.

h) Sistem pengawasan dan pengendalian yang bersifat mendidik mengingat sifat manusia yang tidak sempurna maka efektivitas organisasi menuntut terdapatnya sistem pengawasan dan pengendalian.

Sedangkan Duncan yang dikutip Richard M. Steers (1985) dalam bukunya "Efektrivitas Organisasi" mengatakan mengenai ukuran efektivitas, sebagai berikut:

\section{Pencapaian Tujuan}

Pencapaian adalah keseluruhan upaya pencapaian tujuan harus dipandang sebagai 
suatu proses. Oleh karena itu, agar pencapaian tujuan akhir semakin terjamin, diperlukan pentahapan, baik dalam arti pentahapan pencapaian bagian-bagiannya maupun pentahapan dalam arti periodisasinya. Pencapaian tujuan terdiri dari beberapa faktor, yaitu: Kurun waktu dan sasaran yang merupakan target kongkrit.

\section{Integrasi}

Integrasi yaitu pengukuran terhadap tingkat kemampuan suatu organisasi untuk mengadakan sosialisasi, pengembangan konsensus dan komunikasi dengan berbagai macam organisasi lainnya. Integrasi menyangkut proses sosialisasi.

\section{Adaptasi}

Adaptasi adalah kemampuan organisasi untuk menyesuaikan diri dengan lingkungannya. Untuk itu digunakan tolak ukur proses pengadaan dan pengisian tenaga kerja.

Mengacu beberapa pendapat para ahli di atas tentang efektivitas, pelaksanaan teaching factory di SMK dikatakan efektif apabila mampu memenuhi unsur-unsur sebagai berikut.

1. Pengelolaan program terintegrasi dan adaptif, melalui proses analisis dan perumusan kebijakan yang mantap, berkaitan dengan tujuan yang hendak dicapai dan strategi yang telah ditetapkan.

2. Penyusunan program yang tepat dan dijabarkan dalam program-program pelaksanaan.

3. Tersedianya sumber daya manusia dan sarana/prasarana yang baik.

4. Sistem pengawasan dan pengendalian pelaksanaan program.

5. Kerjasama terkoordinasi dan sinergis.

\section{METODE PENELITIAN}

Penelitian ini menggunakan pendekatan kuantitatif dan kualitatif dengan metode analisis data sekunder dan survey. Data sekunder bersumber dari data statistik yang diterbitkan oleh Badan Pusat Statistik, Kementerian Pendidikan dan Kebudayaan terkait dengan data input dan output sistem pendidikan, seperti data guru, saranaprasarana, pendanaan pendidikan, hasil prestasi akademik siswa dan data APBS tahun 2017/2018. Data primer diperoleh dari survei sekolah khususnya terkait dengan pelaksanaan unit produksi melalui model pembelajaran teaching factory: 1) mengidentifikasi karakteristik SMK yang penyelenggara teaching factory, (2) dan mengkaji pelaksanaan teaching factory (3). Analisis data dilakukan secara deskriptif.

Penelitian dilakukan di 5 wilayah dengan jumlah sampel sebanyak 15 SMKN bidang Pariwisata, pada program keahlian akomodasi perhotelan dengan kategori SMK baik dan sedang yang telah melaksanakan model teaching factory. Subyek untuk pengumpulan data dan informasi adalah kepala sekolah, guru produktif dan pengelola teaching factory. Analisis kajian ini mengacu pada panduan teaching factory yang disusun oleh Direktorat Pembinaan SMK meliputi aspek pengelolaan teaching factory, pelaksanaan pembelajaran, kegiatan produksi dan hasil industri.

\section{HASIL PENELITIAN}

A. Pengelolaan Program teaching factory

1. Perencanaan teaching factory

Perencanaan program teaching factory di SMK kondisinya sangat variatif, hal ini terkait dengan pemahaman sekolah terhadap 
teaching factory. Perencanaan pelaksanaan teaching factory umumnya tidak dari awal, namun merupakan tindak lanjut dari keberadaan unit produksi yang sudah ada di sekolah sebelumnya sehingga dalam perencanaannya sekolah tinggal menganalisis kekuatan dan kelemahan kondisi yang ada secara mendalam terkait dengan peralatan yang ada dan jenis produk/jasa yang akan dilaksanakan sesuai dengan program keahliannya.

Pelaksanaan teaching factory di SMK di masing-masing wilayah baik dari jumlah program keahlian maupun pelaksanaannya cukup beragam, hal ini terkait dengan pilihan program keahlian yang dianggap unggul sesuai dengan kebutuhan, keberadaan SDM, mitra industri, dan fasilitas yang tersedia di masing-masing wilayah dan sekolah. Sebagai contoh untuk wilayah kota Padang ada dua SMK yang menjadi sasaran evaluasi yaitu SMKN 9 dan SMKN 6 Kota Padang. Untuk SMKN 9 Kota Padang hanya ada 2 program keahlian yang dipilih sebagai pelaksanaan teaching factory. Hal ini berdasarkan hasil analisis bahwa dua program ini telah menjadi program unggulan sejak lama sebelum adanya program Tefa dan telah dikenal oleh masyarakat yaitu edotel SMKN 9 dan katering jamaah haji SMKN 9. Sementara untuk SMKN 6 Kota Padang berdasarkan hasil identifikasi sekolah terdapat 4 program keahlian yang menjadi model teaching factory yaitu, edotel Minangkabau SMKN 6 Edo dressmaking SMKN 6, Edocatering Cimpago, dan Edo mutiara salon SMKN 6. Sementara di Kota denpasar 2 sekolah yang menjadi sampel yaitu SMKN 5 Denpasar dan SMKN 3 Denpasar. Di SMKN 3 Denpasar terdapat 4 program studi yaitu akomodasi perhotelan, tata busana, tata kecantikan, dan tata boga. Dari empat program keahlian tersebut yang dipilih untuk menjadi model teaching factory adalah jasa laundry, salon, tata busana, dan tata boga.

Di daerah sampel lainnya yaitu kota Bandung, Kota Surakarta, dan Kota Malang, SMK yang dipilih menjadi subjek dalam kajian mempunyai kecenderungan yang sama dalam menentukan program teaching factory, yaitu berdasarkan pada program keahlian yang sudah mempunyai unit usaha. Program yang dipilih menjadi model teaching factory umumnya berdasarkan pada unit produksi yang sudah ada di sekolah, dan merupakan program unggulan sekolah. Sebagai contoh, sekolah-sekolah yang sudah mempunyai edotel (education hotel) dengan jumlah kamar cukup dan fasilitas baik, dijadikan sebagai model teaching factory. Demikian pula pada program keahlian tata boga, tata busana, tata kecantikan, dan usaha perjalanan wisata.

Perencanaan program terkait dengan produk/jasa yang akan dihasilkan umumnya masih pada jenis produk berdasarkan pesanan, belum sampai pada inovasi produk, banyaknya produk yang akan diproduksi, dan keberlanjutan produk.

\section{a. Struktur Organisasi, Standar Operasional Prosedur (SOP) dan Alur} Kerja

Pada panduan teaching factory disebutkan bahwa struktur organisasi teaching factory dikeluarkan oleh kepala sekolah sesuai standar industri dan terintegrasi dengan struktur sekolah mencakup tugas/lingkup kerja. Struktur organisasi teaching factory terkait dengan keberadaannya di sekolah, ada tiga versi yaitu di bawah pengelolaan koperasi, sekolah, dan bentuk Badan Layanan 
Umum daerah (BLUD). Struktur organisasi yang umumnya mempunyai kecenderungan yang sama, yaitu menggunakan struktur unit produksi yang sudah ada sebelumnya yang ditandatangani oleh kepala sekolah. Bentuk struktur organisasi pada masing-masing SMK bervariasi sesuai dengan kebutuhan dan pemahamannya masing-masing, secara umum terdiri dari penasehat, ketua, sekretaris, bendahara, dan koordinator unit produksi. Namun untuk SMK yang sudah BLUD maupun yang akan mengarah BLUD struktur organisasinya terdiri dari; kepala TEFA, manager produksi, manager pemasaran, manager keuangan dan administrasi, dan di bawahnya adalah koordinator masing-masing unit produksi. Untuk SMK BLUD saat kajian ini dibuat baru ditetapkan pada akhir September 2018, sehingga informasi lebih lanjut belum dapat diperoleh.

Standar Operasional Prosedur (SOP) untuk masing-masing program keahlian di SMK umumnya sudah ada, tetapi belum semua SMK selalu menempelkan panduan pada tempat yang strategis. Untuk pola pekerjaan atau alur kerja umumnya sudah ada dilakukan berdasarkan kebiasaan saja belum dibuat prosedur tertulis sebagai pedoman pelaksanaan pekerjaan. Hanya ada satu program keahlian yang telah mengacu pada prosedur standar/baku yaitu jasa katering haji yang telah mengacu pada standar PT Garuda Indonesia ACS.

\section{b. Administrasi Keuangan}

Pencatatan administrasi keuangan pelaksanaan teaching factory (Tefa) di sekolah sasaran sebagian besar telah melaksanakan pencatatan keuangan dari hasil kegiatan teaching factory sesuai dengan program keahliannya masing-masing, namun pencatatan transaksi pada masingmasing program keahlian belum sepenuhnya mengacu pada prosedur akuntansi yang standar. Sebagian kecil sekolah yang telah mencatat keuangan mengacu pada standar prosedur akuntansi, umumnya sekolahsekolah yang Tefa-nya sudah berjalan baik dan telah berbentuk Badan Layanan Umum Daerah (BLUD) dan yang menuju BLUD. Pencatatan transaksi umumnya dilakukan oleh bendahara pada unit produksi masing-masing secara harian, selanjutnya dilaporkan pada bendahara unit produksi pusat (UP pusat). Pencatatan administrasi keuangan umumnya mempunyai kecenderungan yang sama yaitu dilakukan oleh unit produksi masing-masing terkait dengan hasil penjualan produk/jasa yang dilaporkan kepada UP pusat, selanjutnya UP pusat melaporkan kepada kepala sekolah. Hal ini dikarenakan manajemen Tefa belum berjalan dengan sesuai dengan panduan Tefa.

c. Pemahaman sekolah terhadap Tefa

Dari hasil diskusi kelompok terpumpun di lima wilayah sasaran evaluasi teaching factory terlihat bahwa pemahaman kepala sekolah, guru, dan penanggung jawab teaching factory umumnya masih kurang, baik pada tataran konsep maupun pelaksanaannya. Hal ini dikarenakan semua sekolah sasaran evaluasi belum mempunyai panduan dan belum mendapatkan pelatihan tentang teaching factory. Namun hal itu tidak mengurangi semangat mereka untuk mendapat pengetahuan tentang teaching factory dengan mencari informasi sendiri agar dapat melaksanakannya. Banyak di antara mereka mengadakan diskusi di sekolah dengan mengundang narasumber secara mandiri untuk menambah pengetahuan terkait teaching factory. 


\section{Pelaksanaan Pembelajaran}

Pembelajaran model teaching factory diselenggarakan dalam bentuk pembelajaran berbasis produksi/jasa yang mengacu pada standar dan prosedur industri yang dilaksanakan dalam suasana dan budaya industri. Terkait dengan hal tersebut terdapat tiga komponen yang akan dianalisis yang terkait dengan pelaksanaan pembelajaran, yaitu kurikulum, rencana pelaksanaan pembelajaran, dan tenaga pendidik atau sumberdaya yang terlibat.

\section{a. Kurikulum}

Pada panduan pelaksanaan teaching factory kurikulum yang akan digunakan harus dilakukan sinkronisasi secara kontekstual terhadap tuntutan kebutuhan dan perkembangan industri. Hasil evaluasi di SMK sasaran penggunaan kurikulum dalam kegiatan pembelajaran model teaching factory umumnya menggunakan kurikulum 2013 dan sebagian besar belum melakukan sinkronisasi kurikulum sesuai tuntutan kebutuhan industri. Namun demikian terdapat beberapa sekolah yang dapat menjadi praktik baik yang telah melaksanakan sinkronisasi kurikulum dengan industri pasangan sesuai dengan tuntutan kompetensi yang akan dicapai. Sekolah-sekolah tersebut di antaranya adalah SMKN 9 Kota Padang, SMKN 2 dan SMKN 3 Kota Malang. Untuk SMKN 9 kota Padang sinkronisasi dengan melakukan MOU dengan industri catering dengan anak perusahaan PT Garuda Indonesia. Sementara untuk SMKN 2 Malang Sinkronisasi kurikulum juga dilakukan oleh SMKN 2 Malang pada program keahlian akomodasi perhotelan, yang bekerjasama dengan Swiss Belhotel dengan membuka SMK kelas industri, sehingga kurikulum yang digunakan hasil kerjasama Swiss-bel dan SMK. Untuk SMKN 3 Malang pada program keahlian tata kecantikan yang telah bekerjasama dengan PT Loreal untuk penyusunan kurikulum dan mendatangkan guru pengajar.

Program keahlian akomodasi perhotelan yang bekerjasama dengan Swiss-bel menyelenggarakan pembelajaran dengan mendatangkan manager Swiss-bel sebagai pengajarnya. Kurikulum yang digunakan adalah merupakan sandwich curriculum level 1, yaitu broad based curriculum yang mengedepankan sikap disiplin, karakter, grooming, dan sopan santun.

Dari hasil diskusi juga didapatkan salah satu kendala pelaksanaan Tefa terkait dengan kurikulum yakni banyak muatan kurikulum pada kompetensi inti dan kompetensi dasar yang tidak semua sesuai dengan kompetensi produk/jasa yang akan dilaksanakan. Di dalam kurikulum muatan kompetensi inti dan kompetensi dasar jumlahnya banyak, sementara untuk membuat suatu produk/ jasa hanya perlu kompetensi saja. hal ini membuat para guru bingung untuk memilih kompetensi yang mana. Kalau kegiatan pembelajaran mengikuti kompetensi berdasarkan produk yang akan dibuat, Kriteria Ketuntasan Minimal (KKM) tidak tuntas dan dikhawatirkan akan berimbas pada hasil ujian. Namun jika mengikuti kurikulum proses pembelajaran jadi memerlukan waktu lama.

\section{b. Rencana Pelaksanaan Pembelajaran (RPP)}

Lingkup pelaksanaan pembelajaran yang dievaluasi dalam kajian ini meliputi; rencana pelaksanaan pembelajaran (RPP) dan lembar kerja sekolah (LKS) kegiatan praktek, kewirausahaan, kegiatan pengajar, berbasis 
industri pada program keahlian akomodasi perhotelan, tata boga, tata busana, dan tata kecantikan.

Pelaksanaan model pembelajaran Tefa pada masing-masing SMK bidang pariwisata bervariasi sesuai dengan pemahaman masingmasing sekolah. Pelaksanaan pembelajaran pada program keahlian akomodasi perhotelan, tata boga, tata busana, dan tata kecantikan di SMK umumnya dilaksanakan dengan berpedoman pada rencana pelaksanaan pembelajaran (RPP) yang telah disusun oleh guru produktif. Dari hasil evaluasi ternyata belum semua guru merencanakan kegiatan model tefa pembelajaran produktif yang terintegrasi dengan kompetensi pada produk yang akan dihasilkan. Penyusunan RPP masih mengacu pada kompetensi inti (KI) dan kompetensi dasar (KD) pada kurikulum 2013 yang tidak terkait langsung dengan kompetensi keahlian pada pelaksanaan praktik, atau dengan kata lain bahwa penyusunan RPP belum mengintegrasikan kompetensi yang akan diperoleh pada mapel produktif.

Untuk kegiatan praktik pembelajaran sebagian besar masih menggunakan jadwal pembelajaran biasa, belum menggunakan jadwal pembelajaran yang dirancang khusus untuk Tefa dengan menggunakan sistem blok dan kontinyu sebagaimana yang terdapat dalam panduan Tefa. Hanya sekitar 30\% Sekolah-sekolah yang sudah menggunakan sistem blok dan kontinyu umumnya sekolahsekolah yang telah melaksanakan Tefa dan telah berbentuk BLUD atau menuju BLUD. Sementara sekolah-sekolah yang baru memulai pelaksanaan Tefa jadwal pelajaran masih menggunakan jadwal sebagaimana biasanya.

\section{c. Sumber Daya Manusia (SDM)}

Kesesuaian antara kompetensi keahlian tenaga pendidik SMK bidang pariwisata di sekolah-sekolah sampel rata-rata sudah sesuai dengan bidang keahlian yang diampu, namun hampir semua sekolah menyatakan kekurangan guru-guru produktif. Karena pengadaan guru-guru produktif jumlahnya sangat terbatas. Apalagi untuk program keahlian usaha perjalanan wisata (UPW) sudah beberapa tahun tidak ada tambahan guru-guru baru, karena formasi yang diminta dari pemerintah daerah adalah S1 pendidikan pariwisata. Sedangkan jurusan ini di perguruan tinggi di beberapa wilayah belum ada, sehingga formasi yang ada tidak terisi. Guru-guru honorer mata pelajaran UPW yang ada di SMK saat ini kebanyakan berpendidikan S1 pariwisata non pendidikan, sehingga tidak dapat mengisi formasi. Demikian pula untuk program keahlian akomodasi perhotelan, juga masih banyak yang kekurangan guru, karena formasi guru program keahlian ini sangat kurang, maka posisi ini banyak diisi oleh guru honorer dan untuk PNS-nya dari program keahlian ganda. Sementara untuk guru-guru tata boga, tata kecantikan dan tata busana jumlah gurunya lebih banyak jika dibandingkan dengan guruguru di program akomodasi perhotelan dan UPW.

Pengalaman kerja industri untuk guruguru produktif pada seluruh program keahlian SMK bidang pariwisata rata-rata masih kurang, hal ini dikarenakan kesempatan untuk mendapatkan magang di industri juga terbatas. Kegiatan magang para guru di beberapa SMK sampel saat ini banyak yang sedang berlangsung. Guru-guru yang banyak mendapatkan peluang magang di industri 
umumnya dari program akomodasi dan perhotelan, sementara untuk program tata busana, tata boga, tata kecantikan dan UPW peluang untuk magang lebih sedikit. Hal ini dikarenakan jumlah industri yang berkaitan dengan program tersebut juga terbatas.

Dari sisi kompetensi seluruh tenaga pendidik yang terlibat dalam program teaching factory telah memiliki kesesuaian kompetensi keahlian dengan unit produksi yang diampu. Namun untuk jumlah guru produktif umumnya masih kurang seperti pada unit produksi laundry.

Sementara sumberdaya manusia sebagai tenaga pendidik/pedampingan dari mitra industri pasangan juga sudah dilakukan di sekolah-sekolah sampel, hanya saja jumlahnya masih sedikit dan belum pada semua program keahlian mendapatkan guru dari industri.

\section{Kegiatan Produksi/Jasa}

Inti dari pelaksanaan model pembelajaran teaching factory adalah pembelajaran berbasis produksi/jasa yang mengacu pada prosedur dan standar di industri. Dari hasil verifikasi lapangan melalui observasi kegiatan produksi/jasa pelaksanaan Tefa di SMK sampel kondisinya bervariasi, dari aspek peralatan (sarana-prasarana), hasil produk/jasa, pemasaran, dan tata kelola keuangan. Lebih lanjut kondisi pada setiap aspek disampaikan sebagai berikut.

Peralatan praktik untuk program keahlian akomodasi perhotelan rata-rata sudah cukup baik. Utamanya untuk kamar, furniture, pendingin ruangan, kamar mandi dan dan perlengkapan lainnya sudah standar hotel bintang 2. Bahkan untuk beberapa edotel seperti di SMKN 3 Malang, SMKN 9
Bandung, SMKN 9 Padang sudah sangat baik. Kelengkapan sarana praktik yang ada sangat mendukung pelaksanaan pembelajaran sehingga kegiatan praktek program akomodasi perhotelan sudah menyerupai industri perhotelan. Suasana di edotel sudah sama dengan kondisi hotel sesungguhnya. Kepemilikan kamar pada masing-masing edotel di SMK sebagai tempat kegiatan praktik sehari-hari bervariasi antara 10 sampai dengan lebih dari 20 kamar. Kelengkapan dan tipe kamar sudah menyerupai hotel tipe standard room, deluxe room, superior room, dan family room. Fasilitas kamar juga dilengkapi AC, TV, dan furniture lainnya. Kamar mandi sudah menggunakan shower, bathtub, dan fasilitas air panas.

\section{Hasil Jasa program Akomodasi Perhotelen}

Pelaksanaan Tefa pada program keahlian akomodasi perhotelan utamanya terkait dengan jasa layanan sewa kamar, akses internet, ruang meeting, restoran, dan laundry. Untuk jasa layanan sewa kamar jumlah kepemilikan kamar edotel rata-rata di atas 10 kamar, bahkan ada yang lebih dari 20 kamar. Dari jumlah itu tidak semua kamar dijual, sekitar 50\% nya untuk kegiatan pembelajaran. Kondisi kamar rata-rata juga sudah cukup baik dilihat dari luas kamar, pendingin ruangan (AC), TV, furniture, kamar mandi dan kelengkapannya. Untuk kamar mandi juga tersedia handuk, shower, shampo, sabun dan perlengkapan lain layaknya hotel bintang 2. Untuk furniture rata-rata juga cukup baik, walaupun sebagian besar furniture model lama, namun terawat dengan baik. Kelas kamar tersedia standard room; deluxe room, dan superior room, dan 
family room dengan variasi tarif dari 250.000 sampai dengan 450.000 .

Edotel SMK juga sebagian besar sudah dilengkapi dengan akses internet dengan layanan free internet 24 jam, sehingga para tamu hotel dapat mengakses internet sewaktuwaktu tanpa dibebani biaya tambahan. Untuk fasilitas ruang meeting Edotel sebagian besar juga sudah dilengkapi dengan ruang meeting kapasitas 50 sampai dengan 100 orang. Sementara untuk jasa laundry sekitar $40 \%$ sudah berjalan dengan baik. Untuk ruang restoran belum semua edotel sampel memiliki, baru sebagian kecil (30\%) yang telah memiliki ruang restoran. Layanan restoran juga belum bisa seperti layanan hotel bintang 2, karena terbatasnya pegawai. Layanan terkait dengan menu sarapan juga masih sederhana umumnya masih diantar ke kamar-masing-masing.

Tingkat hunian setiap bulannya bervariasi, tergantung pada bulan-bulan tertentu. Untuk bulan februari sampai dengan maret biasanya sepi, demikian pula untuk bulan puasa. Di luar bulan itu hunian cukup baik mencapai 40-80\%. Bahkan untuk daerah tujuan wisata, seperti Bali, Padang, Malang, dan solo hunian bisa mencapai 100\%. Pelanggan edotel umumnya dari kalangan pemerintah daerah, LPMP, atau siswa-siswa yang melaksanakan study tour dan wisatawan.

Laporan keuangan untuk jasa edotel pada setiap bulannya umumnya sudah tercatat dengan cukup baik. Hasil keuntungan untuk produk jasa edotel untuk setiap bulannya belum menentu. Hasil keuntungan yang dapat disetor ke bendahara sekolah (UP) sekitar 20-40\%. Dari hasil keuntungan edotel sudah dapat membiayai untuk kegiatan operasional pada setiap harinya. Bahkan untuk beberapa hotel sudah mampu membayar listrik dan telepon dari hasil jasa edotel.

Untuk tenaga pemasaran umumnya SMK belum memiliki tenaga pemasaran secara khusus. Pemasaran edotel umumnya menggunakan brosur dan website, untuk beberapa hotel sudah menggunakan jasa pemasaran melalui jasa online seperti blibli. com.

\section{Kerjasama Industri}

Pelaksanaan model Tefa di SMK kerjasama dengan industri sebagai mitra dalam peningkatan mutu lulusan di masingmasing program keahlian sangat diperlukan, karena melalui dukungan industri kompetensi lulusan SMK menjadi lebih baik. Hasil evaluasi teaching factory kerjasama antara SMK dan industri di masing-masing wilayah untuk program akomodasi perhotelan cukup bervariasi, hal ini terkait dengan kondisi sekolah. Dari hasil diskusi dengan kepala sekolah dan guru-guru produktif kerjasama industri umumnya sudah cukup baik, namun belum maksimal. Hal ini dikarenakan industri-industri yang telah terdaftar dalam mitra industri sekolah mempunyai keterbatasan baik dari sisi sarana maupun sumberdaya manusianya, sehingga usulan program sekolah kadang tidak terpenuhi.

Dari sisi jumlah nama industri yang tercantum dalam daftar mitra di SMK umumnya sudah cukup banyak sesuai dengan program keahlian masing-masing, tetapi bentuk kerjasama dengan pasangan industri yang terdaftar tersebut belum maksimal, masih sebatas pada kegiatan prakerin. Untuk program keahlian akomodasi perhotelan kegiatan penyusunan keselarasan kurikulum antara SMK dan industri umumnya belum 
dilakukan, demikian pula terkait dengan bantuan tenaga pendidik dari industri. Namun beberapa SMK telah bekerjasama cukup baik dengan pihak industri. Bentuknya adalah SMK sebagai tempat kegiatan prakerin, magang, dan bantuan tenaga pengajar seperti dengan Swiss Belhotel, Hotel Grand Hyatt, hotel Ibis. SMK-SMK yang telah menjalin kerjasama dengan industri dengan baik umumnya pada SMK-SMK unggulan.

\section{B. Dampak Program}

Dari hasil diskusi kelompok terpumpun dengan kepala sekolah, dinas pendidikan dan guru-guru produktif dapat disimpulkan bahwa dampak program teaching factory bagi siswa, guru, industri, dan masyarakat di masing-masing wilayah umumnya sudah cukup baik, walaupun pelaksanaan teaching factory belum berjalan maksimal. Hal ini dikarenakan semangat kepala sekolah, guruguru, dan dukungan seluruh warga sekolah dalam pelaksanaan teaching factory cukup baik. Di samping itu, sebelum program teaching factory sekolah-sekolah sasaran juga telah melaksanakan kegiatan pembelajaran berbasis produk/jasa melalui unit produksi yang ada sesuai dengan program keahlian masing-masing. Sehingga dengan adanya program teaching factory sekolah tinggal menyesuaikannya.

Dampak bagi siswa pada masing-masing program keahlian antar wilayah antar SMK bervariasi, namun sebagian besar cukup baik. Indikasinya bagi siswa dilihat dari tingkat keterserapan di industri dan kemampuan berwirausaha. Tingkat keterserapan di industri di masing-masing SMK dan di masingmasing wilayah kondisinya bervariasi, namun secara umum cukup baik. Sebagai contoh untuk wilayah kota Padang SMKN 9 program keahlian akomodasi perhotelan tingkat keterserapannya mencapai 85\%, sisanya $15 \%$ ada yang menjadi pengusaha dan melanjutkan kuliah. Sementara untuk SMKN 6 Kota Padang program keahlian akomodasi perhotelan $75 \%$ lulusan terserap di industri, dan 15\% menjadi pengusaha. Program keahlian busana butik, 20\% bekerja di industri dan $80 \%$ menjadi pengusaha. Untuk program keahlian kuliner $60 \%$ bekerja di industri dan 40\% menjadi pengusaha. Sementara untuk program keahlian tata kecantikan 30\% bekerja di industri dan $70 \%$ menjadi pengusaha salon/tata rias.

Wilayah lainnya di Kota Malang yaitu SMKN2 Malang program keahlian akomodasi perhotelan tingkat keterserapan industri cukup tinggi yakni sebesar 90\%, sisanya 10 $\%$ menunggu pekerjaan dan melanjutkan kuliah. Untuk wilayah kota Bandung yaitu SMKN 9 Kota Bandung, tingkat keterserapan lulusan di industri juga cukup baik. Untuk program keahlian akomodasi perhotelan tingkat keterserapannya sebesar 77,14\%, Sementara untuk SMK-SMK wilayah kota Surakarta, dan Denpasar juga sebagaimana disampaikan dalam diskusi juga cukup baik, hanya saja belum tercatat dengan baik.

\section{(1) Dampak Bagi Guru}

Dampak bagi guru, kegiatan pembelajaran menjadi lebih menyenangkan karena kegiatan praktik sudah menyerupai industri yang dapat menghasilkan produk/jasa yang dapat dijual, sehingga guru dan siswa lebih semangat karena hasil penjualan dari produk praktik dapat digunakan untuk pembelian bahan sebagai alat praktik. Guru juga lebih semangat mengajar, karena memiliki kesempatan untuk meningkatkan kemampuannya pada saat 
praktikum, dan memiliki rasa kebanggaan terhadap prestasi siswa dari produk/jasa yang dihasilkan siswa.

\section{(2) Dampak Bagi Sekolah}

Dampak bagi sekolah, bahwa model pembelajaran tefa dengan unit produksi yang ada dapat menghasilkan produk/jasa yang layak jual sehingga dapat menambah penghasilan sekolah yang dapat digunakan untuk membantu biaya operasional sekolah serta dapat digunakan sebagai media promosi sekolah kepada masyarakat.

(3) Dampak Bagi Lingkungan Sekolah/ Masyarakat

Dampak bagi lingkungan sekolah/ masyarakat dari kegiatan teaching factory ini antara lain masyarakat dapat mengetahui dan memanfaatkan produk/jasa yang dihasilkan oleh siswa SMK, disamping itu di beberapa SMK juga mengadakan pelatihan bagi masyarakat sekitar sekolah yang ingin menambah keterampilannya.

\section{(4) Dampak Bagi Industri}

Dampak bagi industri melalui kegiatan teaching factory ini adalah bahwa industri mendapatkan tenaga kerja yang kompeten dan siap kerja sehingga mengurangi biaya pelatihan di industri. Di samping itu industri juga dapat berkontribusi positif terhadap pengembangan sumberdaya manusia dalam rangka meningkatkan mutu pendidikan khususnya pendidikan kejuruan.

\section{Kontribusi teaching factory Bagi Pendanaan di SMK}

Pada tata kelola teaching factory disebutkan salah satu tujuan teaching factory adalah membantu pendanaan untuk pemeliharaan, penambahan fasilitas dan biaya-biaya operasional SMK, dan peningkatan kesejahteraan (Direktorat Pembinaan SMK, 2017). Terkait dengan hal tersebut pelaksanaan model pembelajaran teaching factory di SMK yang memadukan konsep pembelajaran berbasis produk/jasa berstandar industri yang dimulai sejak tahun 2016 telah banyak mendapatkan tanggapan yang positif. Indikasinya antara lain terlihat dari semangat kepala SMK dan guru untuk dapat melaksanakan Tefa sekolahnya. Berbagai upaya telah dilaksanakan di antaranya adalah sekolah-sekolah yang belum pernah mendapatkan pelatihan Tefa bersemangat untuk mendapatkan informasi dari berbagai sumber, bahkan ada SMK yang mendatangkan narasumber dari SMK lain yang telah melaksanakan Tefa.

SMK-SMK yang telah melaksanakan Tefa dengan memilih program keahlian tertentu telah banyak memberikan kontribusi yang positif terhadap peningkatan mutu lulusan, juga telah berkontribusi terhadap pendanaan biaya operasional sekolah. Kontribusi terhadap biaya operasional sekolah umumnya masih relatif kecil misalnya, untuk perbaikan ringan, pembelian bahan-bahan praktik, dan bahkan ada yang sudah mampu untuk membayar listrik pada unit produksinya. Secara umum semua program keahlian SMK bidang pariwisata berpotensi untuk dikembangkan menjadi model teaching factory. Dari hasil diskusi dan observasi di SMK sampel yang telah melaksanakan model teaching factory hasil produk/jasa yang dihasilkan kualitasnya sudah cukup baik dan tidak kalah dari produk industri. Produk/jasa yang dihasilkan oleh SMK ratarata sudah dijual di pasar dan mendapatkan respon yang positif di pasar. Melihat produk/ jasa yang dihasilkan semua SMK berpotensi 
untuk dikembangkan menjadi model teaching factory dan diharapkan kedepannya model tersebut menjadi alternatif strategi pembiayaan di SMK.

\section{Kendala yang dihadapi}

Berdasarkan hasil diskusi dengan kepala SMK dan guru-guru, masih banyak kendala yang dihadapi dalam pelaksanaan teaching factory. Kendala yang dihadapi pada masingmasing SMK beragam, hal ini terkait dengan kondisi SMK masing-masing. Kendala yang dihadapi secara umum dalam pelaksanaan model teaching factory sebagai berikut. (1) Kurangnya SDM pengelola teaching factory (guru-guru mapel produktif) terutama terkait dengan pergantian personil (perpindahan dll). (2) Pembentukan karakter siswa yang perlu terus ditingkatkan agar dapat melayani/ memproduksi produk standar industri. (3) Terbatasnya lahan untuk pelaksanaan Tefa, luas ruang praktik kurang, tidak dapat menyediakan tempat outlet untuk memamerkan produk. (4) Promosi/pemasaran yang masih terbatas pada kalangan tertentu.

(5) Produk/jasa masih tergantung pesanan.

(6) Belum adanya payung hukum yang kuat dalam pelaksanaan Tefa, yang dapat membuat rasa aman kepala sekolah dan guru dalam pelaksanaan tefa di SMK.

\section{KESIMPULAN DAN REKOMENDASI}

\section{Simpulan}

Pengelola teaching factory umumnya belum memahami sepenuhnya konsep teaching factory sehingga dalam perencanaan model teaching factory di SMK belum maksimal, baik dari sisi jumlah program keahlian maupun pelaksanaannya. Perencanaan teaching factory juga belum direncanakan dengan baik. Pelaksanannya baru berdasarkan unit produksi yang sudah ada di sekolah kemudian dilanjutkan dengan model teching factory. Kurikulum yang digunakan kurikulum 2013, sebagian besar belum disinkronkan dengan kurikulum industri. Jadwal pembelajaran teori dan praktik sebagian besar masih menggunakan sistem pembelajaran biasa, belum menggunakan sistem blok.

Sumber daya manusia yang terlibat untuk guru-guru pengelola teaching factory dari sisi jumlah dan pengalaman magang di industri masih kurang. Dari sisi peralatan praktik (sarana-prasarana), hampir semua program keahlian rata-rata sudah cukup baik, hanya ada beberapa yang sarana masih kurang. Untuk program keahlian akomodasi perhotelan dan tata boga rata-rata peralatan sudah cukup baik. Untuk hasil produksi/jasa pelaksanaan teaching factory rata-rata sudah cukup baik, Hasil produk/jasa yang sudah cukup baik khusunya dari akomodasi perhotelan, tata boga, dan tata busana. Produk/jasa dari ketiga program keahlian ini umumnya sudah layak jual dan sudah dapat membantu biaya operasional sekolah untuk perbaikan ringan, dan investasi peralatan sederhana.

Kerjasama antara SMK dengan industri umumnya belum maksimal, karena belum semua program keahlian mendapatkan mitra industri sebagaimana yang diharapkan. Industri yang menjadi mitra yang terdaftar di sekolah umumnya sudah cukup banyak, tetapi bentuk kerjasama dalam pelaksanaan teaching factory masih kurang khususnya terkait dengan keterlibatan dalam penyusunan kurikulum, tenaga pendidik, dan sebagai tempat kegiatan magang guru-guru.

Meskipun masih terdapat kekurangan 
dalam pelaksanaan program teaching factory, namun dampak program teaching factory di SMK bidang pariwisata cukup baik. Dampak bagi siswa tingkat pembelajaran kegiatan praktikum semakin meningkat, dan lulusan menjadi lebih kompeten sehingga lulusannya banyak dibutuhkan industri. Dampak bagi guru kegiatan pembelajaran menjadi lebih menyenangkan karena kegiatan praktik sudah menyerupai industri yang dapat menghasilkan produk/jasa yang dapat dijual, sehingga guru dan siswa lebih semangat karena hasil praktik dapat digunakan untuk pembelian bahan alat praktik. Bagi masyarakat juga dapat ikut belajar keterampilan, serta menggunakan produk/jasa yang dihasilkan dari siswa SMK.

Kendala yang dihadapi secara umum dalam pelaksanaan model teaching factory sebagai berikut. (1) Kurangnya SDM pengelola teaching factory (guru-guru mapel produktif) terutama terkait dengan pergantian personil (perpindahan dll); (2) belum adanya panduan baku Tefa yang mudah dipahami; (3) kurangnya sarana praktik; (4) terbatasnya lahan untuk pelaksanaan Tefa, luas ruang praktik kurang, (5) Promosi/pemasaran yang masih terbatas pada kalangan tertentu; (6) belum adanya payung hukum yang kuat dalam pelaksanaan Tefa, sehingga membuat kepala sekolah dan guru merasa tidak nyaman. Karena ada beberapa pemerintah daerah yang memasalahkan hasil produk/jasa SMKN harus disetor ke kas negara sebagai pendapatan negara bukan pajak (PNBP).

Manfaat yang dirasakan dengan adanya teaching factory dapat memberikan kontribusi yang positif terhadap peningkatan mutu lulusan. Produk/jasa yang telah dihasilkan dari teaching factory sebagian besar telah berkontribusi terhadap biaya operasional sekolah. Walaupun saat ini belum semua program keahlian yang ada di SMK berkontribusi terhadap biaya operasional sekolah. Namun jika teaching factory dapat dikembangkan dan dikelola dengan baik, dapat memberikan tambahan penghasilan bagi SMK dan dapat digunakan untuk membantu dana operasioanal di SMK.

\section{Rekomendasi}

a. Dari hasil kajian dapat direkomendasikan kepada pihak-pihak terkait untuk perbaikan Tefa ke depan, sebagai berikut.

b. Pertama Kementerian Pendidikan dan Kebudayaan hal ini Direktorat Pembinaan SMK perlu memberikan pendampingan, pengiriman juknis melalui e-mail SMK, dan bantuan sarana praktik khususnya pada SMK yang belum mempunyai atau minim peralatan praktik.

c. Kedua pemerintah daerah perlu mendukung pelaksanaan teaching factory dengan membuka formasi/pengangkatan guru-guru produktif untuk mengatasi kekurangan guru, bantuan sarana, dan menerbitkan kebijakan daerah terkait kemudahan SMK mendapatkan akses siswa prakerin dan guru magang serta penggiatan pemanfaatan produk-produk SMK.

d. Ketiga Perlu kebijakan secara khusus yang mengatur pelaksanaan Tefa di SMK terkait dengan Pendapatan Negara Bukan Pajak (PNBP) sebagai badan layanan umum (BLU) SMK agar produk/jasa yang dihasilkan dapat digunakan untuk biaya operasional sekolah. Badan layanan umum SMK perlu dibedakan dengan BLUD lainnya karena sebagai tempat kegiatan pembelajaran dalam rangka peningkatan mutu lulusan. Melalui 
payung hukum yang aman Tefa berpotensi untuk dikembangkan menjadi model pembelajaran yang dapat meningkatkan mutu lulusan dan memberikan tambahan biaya operasional di SMK.

e. Keempat SMK perlu merencanakan pelaksanaan Tefa dengan sebaik-baiknya dengan mengacu pada panduan Tefa dari Direktorat Pembinaan SMK, dan melibatkan seluruh pihak terkait kepala sekolah sebagai pelopor dan inisiator dengan menggerakkan semua komponen yang ada. Sekolah juga perlu menyusun kegiatan pembelajaran teori dan praktik dengan menggunakan, jadwal blok dan worksheet dengan memberikan peluang sebanyak mungkin pada siswa dalam meningkatkan kompetensinya.

f. Menjalin kerjasama secara intensif dengan mitra industri dalam kegiatan prakerin, menyusun kurikulum, dan pedampingan terkait dengan kompetensi keahlian sesuai dengan program keahlian yang ada. Mengevaluasi pelaksanaan Tefa secara periodik, dengan mengacu pada indikator capaian Tefa.

\section{DAFTAR PUSTAKA}

Badan Pusat Statistik (2015,2016, 2017. Tingkat Pengangguran Terbuka (TPT). Jakarta

Clark, dkk. 1998. Financing of Education in Indonesia, Asian Development Bank and Comparative Education Research Centre. Jakarta: The University of Hongkong

Cohn, Elchanan. 1979. The Economic of Education Revised Edition. Massachusetts: A Subsidiary of Harper and Row Publisher Inc.

Direktorat Pembinaan SMK, 2017. Panduan Pelaksanaan teaching factory; Jakarta: Kemdikbud.

Direktorat Pembinaan SMK. 2010. Roadmap Pengembangan SMK 2010-2014. Jakarta: Departemen Pendidikan Nasional.

Direktorat Pendidikan Dasar dan Menengah, Direktorat Pembinaan SMK 2017, Tata Kelola Pelaksanaan teaching factory.

Direktorat Pendidikan Menengah Kejuruan. (2005). Kebijakan Pendidikan Menengah Kejuruan 2005-2009. Jakarta: Direktorat Jenderal Pendidikan Dasar Dan Menengah Departemen Pendidikan Nasional.

Djohar, A. 2007. Pendidikan Teknologi dan Kejuruan. Dalam Ilmu dan Aplikasi Pendidikan. Bandung: Pedagogiana Press.

Emerson, H. 1986. Sistem Birokrasi Pemerintah.CV Mas Agung. Jakarta. Gerungan, W.A.2009. Psikologi Sosial.PT Refika Aditama. Bandung.

Fattah, N. 2009. Ekonomi dan Pembiayaan Pendidikan. Bandung: PT Remaja Rosdakarya.

Faturochman Wawan Pelaksanaan teaching factory (Tefa) Pada Program Keahlian Teknologi Dan Rekayasa di SMK Negeri 4 Semarang 2016

Gasskov, V. 2000. Managing vocational training systems. A handbook for senior administrators. Geneva: International Labour Organization.

Gill, I. S., Fluitman, F., \& Dar, A. 2000. Vocational Education and Training Reform. New 
York: Oxford University Press, Inc.

Hidayat. 1986. Teori Efektifitas Dalam Kinerja Karyawan. Gajah Mada University Press. Yogyakarta

Inpres Nomor 9 Tahun 2016 tentang Revitalisasi Sekolah Menengah Kejuruan dalam rangka Peningkatan Kualitas dan Daya Saing Sumber Daya Manusia Indonesia

Kementerian Pendidikan dan Kebudayaan, Direktorat Jenderal Pendidikan Menengah, Direktorat Pembinaan SMK 2015, Pengembangan teaching factory di SMK, Jakarta.

Kuswantoro, Agung. 2014. teaching factory Rencana dan Nilai Entrepreneurship, Graha Ilmu: Semarang.

Komaruddin.1994. Ensiklopedia Manajemen. Jakarta: Bumi Aksara.

https://www.cnnindonesia.com.

Lubis, Hari S.B \& Huseini, Martani. 1987. Teori Organisasi (Suatu Pendekatan Makro). Jakarta: PAU Ilmu-ilmu Sosial UI.

Lamancusa, J. S., Zayas, Jose L., Soyster, Allen L., et al. (2008). The learning factory: industrypartnered active learning. Journal of engineering education.

M. Agphin Ramadhan Jurnal Pendidikan Vokasi, Vol 5, Nomor 3, November 2015

Peraturan Menteri Pendidikan Nasional Nomor 69 Tahun 2009 Tentang Standar Biaya Operasi Nonpersonalia Tahun 2009 Untuk Sekolah Dasar/Madrasah Ibtidaiyah (SD/MI), Sekolah Menengah Pertama/Madrasah Tsanawiyah (SMP/MTS), Sekolah Menengah Atas/Madrasah Aliyah (SMA/MA), Sekolah Menengah Kejuruan (SMK), Sekolah Dasar Luar Biasa (SDLB), Sekolah Menengah Pertama Luar Biasa (SMPLB), Dan Sekolah Menengah Atas Luar Biasa (SMALB).

Peraturan Menteri Pendidikan dan Kebudayaan Nomor 20 Tahun 2016 Tentang Standar Kompetensi Lulusan Pendidikan Dasar dan Menengah.

Peraturan Pemerintah Republik Indonesia Nomor 29 Tahun1990 Tentang Pendidikan Menengah.

Prosser, C.A. \& Quigley, T.H. (1950). Vocational education in a democracy. Revised Edition. Chicago: American Technical Society.

Pusat Data dan Informasi Pendidikan Balitbang Depdiknas. 2002. Pengkajian Pembiayaan Pendidikan Dari Masa ke Masa. Jakarta: PDIP Balitbang Depdiknas.

Republik Indonesia, Undang-Undang Republik Indonesia Nomor 20 Tahun 2003 Tentang Sistem Pendidikan Nasional.

Reschovsky, Andrew dan Jennifer Imazeki. 2003. Let No Child be Left Behind: Determining the Cost of Improving Student Performance. Public Finance Review, Vol. 31 No. 3, May 2003.

Republik Indonesia, Peraturan Pemerintah Nomor 32 Tahun 2013 Tentang Perubahan Atas Peraturan Pemerintah Nomor 19 Tahun 2005 Tentang Standar Nasional Pendidikan.

Republik Indonesia, Peraturan Pemerintah Republik Indonesia Nomor 48 Tahun 2008 Tentang Pendanaan Pendidikan. 
Siagian, 2008. Efektivitas Organisasi. Erlangga. Jakarta

Suyanto. 2008. Peranan SMK kelompok teknologi terhadap pertumbuhan industri manufaktur. Jakarta: Direktorat Pembinaan Sekolah Menengah Kejuruan, Direktorat Jenderal Manajemen Pendidikan Dasar dan Menengah, Departemen Pendidikan Nasional.

Sugandi, M. 2008. Sustainable Financing Alternatives for Vocational High Schools. Makalah disajikan dalam International Conference on VTE Research and Networking. Nurturing Local VTE Research Efforts: A Response to Global Challenges. Inna Grand Bali Beach Hotel. Bali Indonesia.

Steers Richard. M. 2005. Efektivitas Organisasi. (Terjemahan). Jakarta: Erlangga

Tri Kuat, Seminar Nasional Pendidikan 2018 Implementasi Edupreneurship Melalui teaching factory Pada SMK Program Keahlian Perhotelan Bidang Keahlian Pariwisata.

Wiseman, J. 1987. The Political Economy of Federalism: A Critical Appraisal. Environment and Planning C: Government and Policy 